\title{
DEVELOPING READING COMPREHENSION MATERIALS FOR READING 1st COURSE IN THE SECOND SEMESTER OF SOCIAL AND POLITIC SCI- ENCE FACULTY AT MAHENDRADATTA UNIVERSITY
}

\author{
I Made Arka \\ Fakultas Ilmu Sosial dan Ilmu Politik Universitas Mahendradatta Denpasar \\ e-mail: imdarka73@gmail.com
}

\begin{abstract}
Abstrak - Penelitian ini bertujuan untuk mengembangkan pemahaman materi bacaan untuk Reading I di semester dua fakutas ilmu Sosial dan Ilmu Politik Universitas Mahendradatta. Penelitian ini dikembangkan dengan menggunakan penelitian dan pengembangan yang dianjurkan oleh Sugiyono (2010). Isi dari produk penelitian berdasarkan standar kompetensi dan kompetensi dasar yang disebutkan di dalam silabus. Materi bacaan yang disajikan untuk semester dua pada Reading I dalam pelajaran Bahasa Inggris di Fakultas Ilmu Sosial dan Ilmu Politik Universitas Mahendradatta meliputi kriteria materi bacaan yang baik untuk mendeskripsikan atau menyampaikan topik bacaan di antaranya: (1) Dukacita dan Pelarian, (2) Hasil Pidato, (3) Wanita Karir, (4) Mengunjungi Bali, (5) "Ada Apa dengan Cinta", dan (6) Bagaimana Cara membuat Es krim. Bacaan yang dikembangkan meliputi (1) pengertian tentang teks, (2) menebak teks, (3) mengevaluasi teks, (4) memprediksi teks, (5) mengerti tentang penulisan teks (6) menguraikan kata-kata yang tidak lazim. Produk ini telah di koreksi oleh penguji dan dilakukan tes. Produk dalam bacaan ini diujicobakan selama dua kali. Pertama, diberikan ujicoba terhadap dua puluh orang mahasiwa dan satu dosen di mata pelajaran bahasa Inggris di fakultas Ekonomi Universitas Mahendradatta. Karena ada beberapa butir nomer yang tidak sesuai maka dilakukan revisi. Kedua, dilakukan ujicoba di semester dua dan dua dosen lagi dan hasilnya sesuai. Produk tidak direvisi lagi. Untuk itu bacaan tingkat satu ini di gunakan pada semester dua fakultas Ilmu Sosial dan Ilmu Politik Universitas Mahendradatta.
\end{abstract}

Kata Kunci: Pengembangan, materi dan Pemahaman bacaan

\begin{abstract}
This study aimed at developing good reading comprehension materials for reading 1st course in second semester of Social and Politic Science Faculty at Mahendradatta University. It was developed by using the Research and Development proposed by Sugiyono (2010). The content of the product was based on Competency Standard and Basic Competency mentioned in the syllabus. The reading materials which have been provided for the second grade of reading 1st course in second grade of Social and Politic Science Faculty at Mahendradatta University based on the criteria of a good reading material, involved the reading comprehension materials for reading 1st course that are relevant to convey the topic of (1) Grief and Escape, (2) Speech Production, (3) Career Women, (4) Visiting Bali, (5) “Ada Apa dengan Cinta?", and (6) How to make Ice Cream. The reading comprehension materials, which should be developed, involved the skill of (1) understanding text organization, (2) inferring, (3) evaluating the text, (4) predicting, (5) understanding the writer's style, and (6) dealing with unfamiliar words. The reading materials were corrected by the expert judges and field tested. The product, which was in the form of reading materials, was tried out twice. Firstly, it was tried out to the twenty students of the second semester and one lecturer Mahendradatta University. The result of the analysis showed that there were some invalid items. Then, the product was revised. Secondly, it was tried out in the second semester and two lecturers Mahendradatta University. The results of the analysis showed that all of the items were valid. The product did not need to be revised again. Therefore, it could be used for reading 1st course in second semester of Social and Politic Science Faculty at Mahendradatta University.
\end{abstract}

Keywords: Development, materials and reading comprehension 


\section{Background of the Study}

English is used as a means of communication among people in the world. It has been an international language which plays an important role in developing the relationship between the countries to the other countries in the world. Knowing the importance of English in the world today, students need to be sufficiently equipped with English communication skill.

As one of the English language skills, reading is a very important skill in learning English because without a good reading skill, one cannot obtain many kinds of information printed in the form of media such as bulletin, magazine or newspaper (Koda, 2005). Moreover, students in countries where English is taught as a foreign language usually prefer focussing on information in written form rather than oral. Therefore, in countries posing English as a foreign language, such as Indonesia, one can absorb more knowledge by reading.

Richards (2008:11) states that reading as a cognitive process which includes serious academic reading, reading the comics, scanning the television listings for favourite program, skimming a magazine article to find out whether it merits close attention, settling into a new novel by favourite author, absorbing the subtitles as watch the movie in a foreign language, and glancing at notes a give speech.

Alderson (2000) defines reading as an enjoyable, intense, private activity, from which much pleasure can be derived, and in which one can become totally absorbed. Additionally, Nunan (2003) states that reading is fluent process of readers combining information from a text and their own background knowledge to build meaning. However reading always has a purpose. It is something that we do every day, it is an integral part of our daily lives, taken very much for granted and generally assumed to be something that everyone can do.

Considering the fact that English is a prominent language of transferring knowledge and culture, academicians, especially students in EFL countries who are seeking knowledge should be taught English on the purpose to obtain knowledge, since they do not usually use English in their community. Therefore, EFL-based goal of learning English should be introduced in more considerations.

This research and development was conducted in second semester of Social and Politic Science Faculty at Mahendradatta University. The case is that students are at average level of English proficiency compared to other acredited universities in Bali. Therefore, suitable English reading textbooks for average students are needed specifically for second semester students of Social and Politic Science Faculty at Mahendradatta University.

The reality and condition of reading materials in second semester of Social and Politic Science Faculty at Mahendradatta University: (1) the reading materials in that class did not match with competency standard, basic competency and indicators, (2) pre-reading activities in the materials did not occur in each reading material, (3) the reading materials were lack of clear examples that support the clarity of the reading materials, (4) the contents and lay-out of the reading materials were not attractive and simply monotonous, (5) the colour of materials were black and white, and (6) the reading materials were no pictures.

In the second semester of Social and Politic Science Faculty at Mahendradatta University, can be classification of reading curriculum are (1) Reading 1st is aimed to review reading in pronunciation, reading sentences loudly, and developing their English language skills through reading. (2) Reading 1st deals with using articles 
derived from sentences of a text and filling in gaps in incomplete sentences related to the articles. (3) Reading 1st is aimed to analyze characteristics of genres of texts. (4) Eventually, Reading 1st is meant to enable the students to synthesize topic and grasp the reading materials in an advanced analysis.

Considering the reality and condition of reading materials in second semester of Social and Politic Science Faculty at Mahendradatta University, the researcher conducted specific observations regarding the materials and the guidelines for developing effective English teaching materials in Reading 1st course. Reading 1st course was selected since in this course, the students learn Basic English language skills and principle comprehension techniques in reading. The guidelines were (1) English language teaching materials should be contextualized, (2) English teaching materials should be stimulate interaction and be generative in terms of language (3) English language teaching materials should encourage learner to develop learning skills and strategies, (4) English language teaching materials should allow for a focus on form as well as function, (5) English language teaching materials should offer opportunities for integrated language use,

(6) English language teaching materials should be authentic, (7) English language teaching materials should link to each other to develop a progression of skills, understanding, and language items, (8) English language teaching materials should be attractive, (9) English language teaching materials should have appropriate instructions, and (10) English teaching materials should be flexible. The study was assigned to conduct a study on developing reading comprehension materials for Reading 1st course in second semester of Social and Politic Science at Mahendradatta University. It was developed by using research and development proposed by Sugiyono (2010).

The present study aimed atconducting a study to design materials for teaching reading which can be used by the English lecturers to teach Reading 1st course in second semester of Social and Politic Science Faculty at Mahendradatta University. Furthermore, the reading materials provided (1) about the book, (2) book mapping as the guideline of the activities of each unit, (3) the competency standard and basic competency as the soul in the content of the book, (4) concept mapping as the activities in reading materials involved understanding text organization, inferring, evaluating the text, predicting, understanding the writer's style, and dealing with unfamiliar words. These activities were designed to make the students enjoy in learning reading materials.

\section{Research Method}

The design of this study was based on Research and Development (Sugiyono, 2010), the findings of which was used to develop a new product.

This research was a preliminary research and development ( $\&$ \& ) since the aim of this research was to design a new product of reading comprehension materials for Reading 1st course in second semester of Social and Politic Science Faculty at Mahendradatta University in terms of their appropriateness towards syllabus and criteria of good reading comprehension materials. In addition, there were some developments of related materials and exercises regarding the weaknesses of the recent textbook being used.

The step of the study involved (1) identifying problems, (2) data collection, (3) product design, (4) design validation, (5) testing the 1st product, (6) design revision, (7) product revision, (8) testing the 2nd product, (9) product revision, (10) fi- 
nal product.

In this research, students who were taking Reading 1st course in second semester of Social and Politic Science Faculty at Mahendradatta University were considered as population. This present study had been conducted in reading 1st course where there were twenty students which were distributed into 1 (one) classes in the second semester.

Individuals in this population shared at least one characteristic in common that they were in the same grade. The state of equality means that everyone in the population has the same chance or opportunity to be selected as part of the sample. Furthermore, taking sample randomly in systematic way will fulfill the demand of equality. In this study, Cluster sampling technique had been applied to obtain the sample of the study. Through lottery, one class were selected. In order to choose the control group and experimental group from the class, another lottery technique was conducted to ensure that the class had equal chance. The result of the lottery technique revealed that the group in class was taken as the experimental group and the other group considered as the control group.

\section{Finding and Discussion}

The appropriate topics which had been developed for Reading 1st course in second semester of Social and Politic Science Faculty at Mahendradatta University based on Curriculum, involved (1) Grief and Escape, (2) Speech Production, (3) Career Women, (4) Visiting Bali, (5) "Ada Apa dengan Cinta," and (6) How to make Ice Cream. Furthermore, additional reading topics need to be developed in order to supply the missing materials which were required by the curriculum. A good reading material should be contextualized to topics and themes that provide mean- ingful, purposeful uses for the target language.

The activities which are needed to be developed are the activities which are appropriate with good reading materials based on Greenall.S and Pye.D (2005). The activities of reading materials produced in this research have six parts, namely: (1) understanding textual organization, (2) inferring, (3) evaluating text, (4) predicting, (5) understanding the writer's style, and

(6) dealing with unfamiliar words.

A contextual material is a must, where in this product all materials delivered are contextual and related to the reader daily activities. It means that all materials should be contextualized to topics and themes that provide meaningful, purposeful uses for the target language. As one example provided in the product that the material is contextual is presented in the topic of "Grief and Escape" here, the situation in Bali in preparing concept how to be alert when tsunami comes and how to be prepared for upcoming accident. This topic is very contextual since human being should prepare for the accident that may happen incidentally. Good materials should be contextualized. Moreover, all materials presented in this product could stimulate interactions and be generative in term of language meaning. Then students can do interaction and generate learning language through the activities. Also, this product could encourage the students to develop learning skills and strategies which are also a part of the development of the product where all material could attract students to learn something from the reading material where they will know about the form of the text and also the function of the text through reading.

The integration of language use was also considered in the production of this product so it will allow student to integrate the language skills and improve their 
language quality. In term of authenticity, all reading materials were taken from a credible source and already fulfilled what so-called authentic material by considering language, purpose and the use of language. Furthermore, to attract students' attention, all materials are presented in a very attractive form and also attractive topic, because the selection of the material should be based on attractive topics too.

In relation to the design of material or the presentation of material, good and clear instruction are also provided to guide students to work through the reading materials. As a basic consideration so that this product match with the curriculum, the production of this product also considered the competency standard so that it matches with the curriculum. Moreover the presentation of the materials is also typed neatly and has sub headings. The sub headings are bolded and given different color. Consistent with the font point, space and text, assignment, exercises and feedback, in every unit is presented by using appropriate picture, bold or italic text. One more important thing to attract the first sight to this product, a beautiful cover was designed and all the arrangements of the activities including all contents were arranged well. All of what have been mentioned before especially designing color; shape and etc. were conducted to attract students feeling in reading.

\section{Conclusion}

There are four conclusions drawn based on the findings. They are as follows.

1. The topic of good reading materials for Reading 1st course in second semester of Social and Politic Science Faculty at Mahendradatta University are compatible with the reading materials for the Curriculum, and the orderly presentation of the topic in the material that fulfill the requirements of the Competency
Standard and Basic Competency of the Curriculum for Reading 1st course in second semester of Social and Politic Science Faculty at Mahendradatta University. The Reading topics were divided into two sessions namely; 1) the topics given before mid-semester test: Grief and Escape, Speech Production, and Career Women. 2) the topics given post mid-semester test such as Visiting Bali, "Ada Apa dengan Cinta", How to make Ice Cream, and Evaluation.

2. The reading activities which need to be developed for Reading 1st course in second semester of Social and Politic Science Faculty at Mahendradatta University are the activities which are appropriate with Curriculum and the criteria of good reading material. The activities are 1) the activities which have an understanding text organization, 2) the activities which need inferring, 3) the activities which are for predicting, 4) the activities which are for evaluating the text, 5) the activities which are for an understanding the writer's style, and 6) the activities which deal with unfamiliar word.

3. The characteristics of good reading materials for reading 1st course in second semester of Social and Politic Science Faculty at Mahendradata University based on the criteria of good reading material are: 1) Reading material must have an impact on the students, 2) Reading material must give exposure to real language, 3) Reading material must support students' autonomy and independence, 4) Reading material must be developed with different levels of difficulties, 5) Reading materials must encourage the students to develop learning skills and strategies, 6) Reading material must have appropriate instructions, and (7) Reading material must be attractive. 
4. The reading materials were developed by using the research and development proposed by Sugiyono (2010). It consisted of ten steps, namely; 1) identifying the problem, 2) collecting the data, 3) designing the product, 4) validating the design, 5) revising the design, 6) testing the 1 st product, 7) revising the product, 8) testing the 2 nd product ,9) revising the product, and 10) final product. The product was tried out twice. Firstly, it was tried out by taking out one class. The participants were twenty of second semester of Social and Politic Science Faculty at Mahendradatta University. There were some invalid items. Then, the product was revised based on the result of analysis and suggestion from the supervisors and expert's judges. Secondly, it was tried out in second semester of Social and Politic Science Faculty at Mahendradatta University by using clusters sampling. Because all of the items were valid, the product was not revised. In order words, the product could be used to Reading 1st Course in second semester of Social and Politic Science Faculty at Mahendradatta University.

\section{Suggestions}

This research was a preliminary research aiming at developing reading material for Reading 1st course in second semester of Social and Politic Science Faculty at Mahendradatta University. Further study still needs to be done to this particular material. Lecturers and other researchers are encouraged to develop their own materials for different level of students and also different focus of language skills, such as writing, listening, and speaking. Moreover the result of this research still needs a broader scope of field testing in order to get a better result.

Implication

In relation to the result of this research, there are some implications as follows:

1. This material is suitable for Reading 1st Course in second semester of Social and Politic Science Faculty at Mahendradatta University. It was developed based on the content of School-Based Curriculum for second semester of Social and Politic Science Faculty at Mahendradatta University, the criteria of good reading material, and also the needs of lecturer of second grade of Social and Politic Science at Mahendradatta University.

2 This material can be used for the targeted audience since the result of analysis shows that the material meets the School-Based Curriculum and the criteria of good reading material.

\section{REFERENCES}

Alderson. J. C. 2000. Assessing Reading. Techniques for testing reading ( $\mathrm{pp}$ 202-270). Cambridge University Press.

Greenall. S, Pye, D. 1991. Reading 1, Student's Book. Cambridge University Press.

Koda. K. 2005. Insight into Second Language Reading. Theory into Practice (pp 227-271). Cambridge University Press.

Nunan David. 2003. Practical English Language Teaching. New York:The McGraw-Hill Companies, Inc.

Richard. J. C. 1998. Extensive Reading in the Second Language Classroom. The Practice of Extensive Reading (pp 81-167). Cambridge University Press.

Sugiyono. 2010. Metode Penelitian Pendidikan. Bandung : Penerbit Alfabeta. 